\title{
Rapid detection of wheat yellow mosaic virus by reverse transcription loop-mediated isothermal amplification
}

\author{
Zong-Ying Zhang, Xiao-Jun Liu, Da-Wei Li, Jia-Lin Yu and Cheng-Gui Han*
}

\begin{abstract}
For the detection of wheat yellow mosaic virus (WYMV), we established a reverse transcription loop-mediated isothermal amplification (RT-LAMP) method. Using Primer Explorer software, four sets of primers were designed and RT-LAMP assay reaction conditions were optimized. The RT-LAMP was performed at different times by four primer sets. Agarose gel analysis showed that WYMV could be detected after 30 min with the primer set III and after 45 min with the other three primer sets, both under the 80-min reaction time. RT-LAMP had the same results with the four primer sets, thus primer set III and $65^{\circ} \mathrm{C}$ for 80 min reaction were selected for virus detection. There was no significant different when avian myeloblastosis virus (AMV) and moloney murine leukemia virus (M-MLV) RT-LAMP with the four primer sets and M-MLV was chosen due to its relatively cheap price. The result on specificity showed that the assay could amplify WYMV specifically, and the sensitivity comparison showed that the RT-LAMP was 100 times more sensitive than conventional reverse-transcriptase-polymerase chain reaction (RT-PCR). Overall, RT-LAMP was found to be a simple, specific, sensitive, convenient and time-saving method for WYMV detection.
\end{abstract}

Keywords: Wheat yellow mosaic virus, RT-LAMP, Virus detection

\section{Background}

Wheat yellow mosaic is one of the most devastating soil-borne diseases of winter wheat (Triticum aestivum L.). It was first reported in Japan in the 1920s and China in the 1960s [1,2], and then spread continually in Japan and China $[3,4]$. According to the statistical data, the disease area was more than 666,700 hectares in the 1990s, the yield loss was estimated to range between 20$40 \%$ and could be up to $70-80 \%$ during a serious year, even $100 \%$.

Wheat yellow mosaic virus (WYMV), the causal agent of wheat yellow mosaic, belongs to the genus Bymovirus within the family Potyviridae. It is a soil-borne pathogen and is transmitted by the fungus-like organism Polymyxa graminis [5]. The genome of WYMV is comprised of two $(+)$ single-stranded RNAs, RNA1 encodes for coat protein $(\mathrm{CP})$ and six others: $\mathrm{P} 3,7 \mathrm{~K}$, nuclear inclusion protein a $(\mathrm{NIa})$, nuclear inclusion protein $\mathrm{b}(\mathrm{NIb})$,

\footnotetext{
* Correspondence: hanchenggui@cau.edu.cn

State Key Laboratory for Agrobiotechnology and Department of Plant Pathology, China Agricultural University, Beijing 100193, China
}

cytoplasmic inclusion protein $(\mathrm{CI}), 14 \mathrm{~K}$; RNA2 encodes for a polyprotein that contains $28-\mathrm{kDa}$ and $72-\mathrm{kDa}$ proteins $[6,7]$.

Concerning virus detection, several methods are used commonly to detect WYMV. ELISA is a reliable method for detecting WYMV and suitable for high-throughput samples [8-10]; RT-PCR is the most conventional method to detect RNA virus $[11,12]$ and western blotting detects the target protein for further confirmation [13-16]. However, the sensitivity of ELISA might not be sufficiently high to detect low concentrations of WYMV, and virus-specific antiserum is required. WYMV can serologically cross-react with wheat spindle streak mosaic virus [17], and RT-PCR is not perfect either.

Novel nucleic acid amplification methods, loopmediated isothermal amplification (LAMP) for DNA and RT-LAMP for RNA, have been developed [18]. The high specificity and sensitivity, rapid execution, performance under isothermal condition, time-saving, easy observation of by-products [19], and low cost make RTLAMP unrivaled among diagnostic techniques. It is easy
C Biomed Central

C 2011 Zhang et al; licensee BioMed Central Ltd. This is an Open Access article distributed under the terms of the Creative Commons Attribution License (http://creativecommons.org/licenses/by/2.0), which permits unrestricted use, distribution, and reproduction in any medium, provided the original work is properly cited. 
and simple to perform only with four appropriate primers, a reverse transcriptase for RNA template, a DNA polymerase and a water bath or heat block for reaction. Therefore, in recent years, many pathogenic viruses have been detected by these methods, including human [20-24], animal [25] and plant [26-32] viruses.

In the present study, the RT-LAMP method was used successfully for detection of WYMV for the first time. This method could result in more accurate diagnosis for monitoring WYMV.

\section{Materials and methods Plant materials}

Wheat samples were collected during field surveys from different regions of China in March 2011 and stored in a freezer at $-20^{\circ} \mathrm{C}$. The Chinese wheat mosaic virus (CWMV)-infected samples were collected from Yantai, Shandong Province; the barley stripe mosaic virus (BSMV)-infected samples were fresh wheat leaves inoculated with BSMV in our laboratory in May 2011.

\section{Total RNA extraction}

The fresh or stored wheat samples were ground in a Retsch MM400 mixer mill (Retsch, Haan, Germany) for $1 \mathrm{~min}$ at $30 \mathrm{~Hz}$, the sample powder was homogenized with $600 \mu \mathrm{l}$ extraction buffer $(0.1 \mathrm{M}$ Tris- $\mathrm{HCl}, \mathrm{pH} 7.4$, $2.5 \mathrm{mM} \mathrm{NaCl}$, and EDTA) and $600 \mu \mathrm{l}$ supercritical water-phenol, then centrifuged at 12,000 rpm for 15 min. The aqueous phase was precipitated with $4 \mathrm{M}$ $\mathrm{LiCl}$. After incubation at $-20^{\circ} \mathrm{C}$ for $2 \mathrm{~h}$ or overnight, the precipitate was collected by centrifugation $(12,000 \mathrm{rpm})$ at $4^{\circ} \mathrm{C}$ for $15 \mathrm{~min}$. The resultant pellet was washed twice with $70 \%$ ethanol, dried at $37^{\circ} \mathrm{C}$ for about $5 \mathrm{~min}$, and dissolved in $60 \mu \mathrm{l}$ deionized distilled water. The RNA extract was stored at $-20^{\circ} \mathrm{C}$.

\section{Primer design}

Based on published WYMV RNA1 and RNA2 sequences (accession numbers AF067124 for RNA1and AF041041 for RNA2) [7], four sets of primers were designed by Primer Explorer version 4 (Fujitsu Ltd., Tokyo Japan, http://primerexplorer.jp/elamp3.0.0/index.html). Four oligonucleotide primers [F3, B3, FIP (F1c + F2), and BIP $(\mathrm{B} 1 \mathrm{c}+\mathrm{B} 2)]$ that recognize a total of six sequences of the $\mathrm{CP}$ gene and the $72 \mathrm{kDa}$ gene were designed, respectively. F3 and B3 were outer primers whereas FIP and BIP are inner primers. Each inner primers has two distinct adjacent sequences in opposite orientations. All primers were PAGE purified and synthesized by Invitrogen or Sanggon (Shanghai, China).

\section{RT-LAMP detection}

To choose the most appropriate primer set, RT-LAMP reactions were conducted as described previously
$[18,19,33]$. The reaction was carried out in a $25-\mu l$ reaction system, containing $2.5 \mu \mathrm{l} 10 \times$ Thermopol buffer, $0.5 \mathrm{mM}$ dNTP, $0.8 \mathrm{M}$ betaine, $1.6 \mu \mathrm{M}$ FIP and $1.6 \mu \mathrm{M}$ BIP, $0.2 \mu \mathrm{M}$ F3 and $0.2 \mu \mathrm{M}$ B3, $0.45 \mathrm{mM} \mathrm{MgCl}_{2}$ and 1.8 mM DTT, 4U RNase Inhibitor (TaKaRa, Biotechnology, Dalian, China), $200 \mathrm{U}$ moloney murine leukemia virus (M-MLV) transcriptase or $1.25 \mathrm{U}$ avian myeloblastosis virus (AMV) reverse transcriptase (Promega, Madison, WI, USA), 8 U Bacillus stearothermophilus (Bst) DNA polymerase (New England Biolabs, Ipswich, MA, USA), $1.0 \mu \mathrm{l}$ RNA extract and $4.0 \mu \mathrm{l}$ deionized distilled water. Four sets of primers (I-IV) located in the CP and the 72 $\mathrm{kDa}$ gene, were used to detect WYMV at $65^{\circ} \mathrm{C}$ for $25-80$ $\mathrm{min}$, and to compare RT-LAMP in the presence of MMLV or AMV reverse transcriptase. The final products of RT-LAMP were a mixture of stem-loop DNAs with various stem lengths and cauliflower-like structures with multiple loops. For WYMV-positive sample, the linearized DNA form showed up in the lane by agarose gel analysis. Many pyrophosphate ions were produced during RT-LAMP, and the production of a white precipitate of magnesium pyrophosphate gave the tube a turbid appearance that could be observed directly. The positive tube was cloudy and the negative one was clear. With four sets of primers, the RT-LAMP reaction mixture was observed by the naked eye, and the amplification reactions were confirmed by complementary procedures, such as gel electrophoresis. Five microliters of amplified DNA fragments were electrophoresed in 1.5\% agarose in TBE buffer.

\section{Conventional RT-PCR detection}

The RT mixture contained $2 \mu \mathrm{l}$ RNA extract, $0.5 \mu \mathrm{l}$ primer (Table 1), $3 \mu \mathrm{l} 5 \times$ M-MLV buffer and $1 \mu \mathrm{l}$ dNTP (5 mM each), 12 U RRI, 200 U M-MLV reverse transcriptase (Promega, Madison, WI, USA) and $7.5 \mu \mathrm{l}$ deionized distilled water, added to a final volume of $15 \mu \mathrm{l}$. Reverse transcription was performed at $37^{\circ} \mathrm{C}$ for $1.5 \mathrm{~h}$, and $2.0 \mu \mathrm{l}$ product of cDNA was used for PCR amplification. Twenty-five microliters of PCR mixture that contained $2.5 \mu \mathrm{l}$ PCR buffer, $0.5 \mu \mathrm{l}$ dNTP ( $5 \mathrm{mM}$ each), 0.5 $\mu \mathrm{M}$ primers, $1.25 \mathrm{U}$ Taq DNA polymerase (Tiangen, Beijing, China), and $21.5 \mu \mathrm{l}$ deionized distilled water were added. The PCR was performed with denaturation at $94^{\circ} \mathrm{C}$ for $5 \mathrm{~min}$ and 30 cycles of $94^{\circ} \mathrm{C}$ for $40 \mathrm{~s}, 63^{\circ} \mathrm{C}$ for $45 \mathrm{~s}$, and $72^{\circ} \mathrm{C}$ for $40 \mathrm{~s}$, followed by a final $10-\mathrm{min}$ extension step in a Bio-Rad Cycler(Bio-Rad, Hercules, CA, USA). Five microliters of amplified DNA fragments were electrophoresed in 1.5\% agarose in TBE buffer.

\section{Specificity and sensitivity comparison of RT-LAMP and RT-} PCR

To determine the specificity of RT-LAMP, total RNA from wheat leaves infected with WYMV, CWMV or 
Table 1 Primers used for RT-LAMP and RT-PCR

\begin{tabular}{|c|c|c|c|c|c|}
\hline & Primer & Type & Target gene & Sequence $\left(5^{\prime}-3^{\prime}\right)$ & Genome position $^{a}$ \\
\hline & F3-1 & Forward outer & & TGAAACACGGCGCATCTG & $665-682$ \\
\hline \multirow[t]{4}{*}{1} & B3-1 & Reverse outer & $C P$ & AGTTCTGGGTGTCCATCAGT & $875-856$ \\
\hline & FIP-1 & Forward inner & & GCAACTTCGATGTCCTGTGGGTCCGCGTACGCTTITGACT & 752-731,689-706 \\
\hline & BIP-1 & Reverse inner & & AGCACGTCTTGCTGCTTTAGGCGGTTGTCTTGCGGAGGTT & $759-780,837-820$ \\
\hline & F3-2 & Forward outer & & GCAGATCGTGTTGAGGCC & $106-123$ \\
\hline \multirow[t]{4}{*}{$\|$} & B3-2 & Reverse outer & $C P$ & ATAGATTTGGGTGCGCTCTT & $332-313$ \\
\hline & FIP-2 & Forward inner & & CCAGCGTCGGCAACAATTTTGAGCGATGACAAGAAAGCCAG & $212-191,142-161$ \\
\hline & $\mathrm{BIP}-2$ & Reverse inner & & CAAAAAGGACCAATGCCGCCACGAAGCTTTAGTCCTGCGTT & $215-235,293-274$ \\
\hline & F3-3 & Forward outer & & ACTACCATTCTCGCAGCACT & $715-734$ \\
\hline \multirow[t]{4}{*}{ III } & B3-3 & Reverse outer & $72 \mathrm{kDa}$ & GGTCACGAACGACAGTGC & 916-899 \\
\hline & FIP-3 & Forward inner & & GCCGAACCATGGAAAGGTGTCT-TGGCGTTGTTCCTTAGTGC & $813-729,748-767$ \\
\hline & $\mathrm{BIP}-3$ & Reverse inner & & TACTCCCACGGAGGTCCTCC-GCTGGTAAGAAGCATCCCG & $814-833,889-871$ \\
\hline & F3-4 & Forward outer & & GGGGTTTCGAACACGAATGG & $1335-1354$ \\
\hline \multirow[t]{9}{*}{ IV } & B3-4 & Reverse outer & $72 \mathrm{kDa}$ & AGCGAGGCCTCAGCATTA & $1517-1500$ \\
\hline & FIP-4 & Forward inner & & CATGTCCAGTGCTCTTGCGTCG-CATCCACGCTGCAACGAA & $1428-1407,1355-1372$ \\
\hline & $\mathrm{BIP}-\mathrm{V}$ & Reverse inner & & ACGAGCGAGCTTITCCAATCCA-CAAGCAGCGAGACAATGTCA & 1429-1450,1498-1479 \\
\hline & HC72-157 F & Forward Primer & $72 \mathrm{kDa}$ & TGCGAAGCCTCTACGACCTGTTT & $157-179$ \\
\hline & $\mathrm{HC72-518R}$ & Reverse Primer & & TGATGATTGCTCGCCCAACAGA & $518-497$ \\
\hline & CWMV-F & Forward Primer & $19 \mathrm{kDa}$ & TATGACTACTGGTACTCA & $2652-2669$ \\
\hline & CWMV-R & Reverse Primer & & AATTACTCCACACGAGT & $3173-3157$ \\
\hline & BSMV-F & Forward Primer & unknown & CTTGATGCTTTGGATAAGGCTTA & 1864-1887 \\
\hline & BSMV-R & Reverse Primer & protein & AATCTTCCCTTGGGGGAC & $2790-2773$ \\
\hline
\end{tabular}

a Genome position refers to the nucleotide sequence of WYMV-HC CP and 72 kDa genes (accession number RNA1 AF067124 and RNA2 AF041041), CWMV RNA2 19-kDa gene (accession number AJ012006), and BSMV RNA-gamma segment (accession number M16577)

BSMV were applied to the RT-LAMP reaction solution separately, and RNA collected from the healthy wheat served as a negative control. The primer sequences used for CWMV and BSMV RT-PCR were shown in Table 1. To compare the sensitivity of RT-LAMP with RT-PCR, total RNA from WYMV-infected wheat was diluted serially in 10 -fold increments $\left(10^{0}-10^{-8}\right)$ with healthy wheat RNAs were then used as templates for the two assays. The products were analyzed by agarose gel electrophoresis (1.5\% agarose, TBE).

\section{Results}

\section{Primer design and selection of assay reaction conditions}

Four sets of RT-LAMP primers were designed (I-IV). Primer sets I and II were located at 665-875 nt (3' terminal) and 106-332 nt (close to 5' terminal) of the CP gene; and primer sets III and IV were located at 715$916 \mathrm{nt}$ (close to 5' terminal) and 1335-1557 nt (close to 3' terminal) of the $72 \mathrm{kDa}$ gene (Figure 1).

Each set contains four primers, F3 and B3 were outer primers whereas FIP and BIP were inner primers. Each of the two inner primers had two distinct adjacent sequences in opposite orientations. For detecting CP gene, the first sequence (nt 752-731) of FIP-1 and sequence (nt 212-191) of FIP-2 were in reverse orientation, whereas the second sequence (nt 689-706) and sequence (nt 142-161) of the primers were in the forward direction. In BIP-1 and BIP-2, the forward sequence (nt 759-780) and sequence (nt 215-235) is followed by the reverse sequence (nt 813-729) and sequence (nt 293-274). For the $72 \mathrm{kDa}$ gene: the first sequence (nt 813-729) of FIP-3 and sequence (nt 14281407) of FIP-4 were in reverse orientation, whereas the second sequence (nt748-767) and sequence (nt 13551372) of the primers were in the forward direction. In BIP-3 and BIP-4, the forward sequence (nt 814-833) and sequence (nt 1429-1450) is followed by the reverse sequence (nt 889-871) and sequence (nt 1498-1479). Their relative location in the virus genomes were shown in Table 1.

To select the appropriate primer set, RT-LAMP using four sets of primers was carried out with two healthy controls and two virus-infected samples under isothermal condition at $65^{\circ} \mathrm{C}$ for different times. Agarose gel electrophoresis showed that the primer set III had positive bands after $30 \mathrm{~min}$ and the other three sets had positive bands after $45 \mathrm{~min}$. They were all available within $80 \mathrm{~min}$, thus the primer set III seemed more 
(a) RNAI

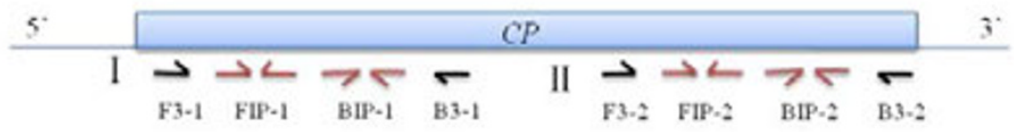

(b) RNA2

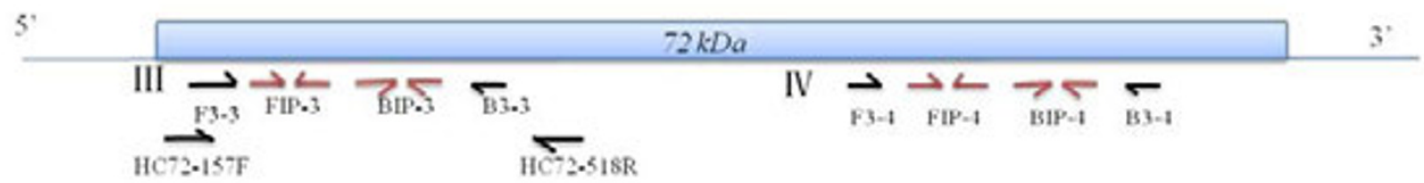

Figure 1 Primer locations. Four sets of primers were designed, named I-IV, which targeted the CP (RNA1) gene and 72 kDa (RNA2) gene of WYMV. HC72-157 F and HC72-518R were the conventional RT-PCR primers

sensitive than the others and was selected for virus detection under isothermal conditions at $65^{\circ} \mathrm{C}$ for 80 min in this study (Figure 2). For each primer set, AMV and M-MLV RT-LAMP was performed and similar results were obtained, therefore, M-MLV reverse transcriptase was chosen for the subsequent RT-LAMP assay because of its relatively cheap price (Figure 3).

The turbidity of pyrophosphate ions was observed directly after production of large amounts of DNA fragments during the RT-LAMP reaction. RT-LAMP reaction mixtures were used for turbidity observation with the primer sets I-IV after reaction at $65^{\circ} \mathrm{C}$ for $80 \mathrm{~min}$. The healthy controls were relatively clear, whereas the positive samples were cloudy, and primer sets I and III more readily gave negative or positive results (Figure 4). This demonstrates that the RT-LAMP reactions are conveniently visualized by directly judging the turbidity and it does not require specialized PCR and electrophoresis equipment. The primer set III was chosen for the following experiments.

\section{Specificity and sensitivity comparison of RT-LAMP and RT- PCR}

To evaluate the specificity of RT-LAMP, it was carried out using two healthy controls, two WYMV-infected, two CWMV-infected and two BSMV-infected samples with WYMV RT-LAMP primer set III. At the same time, the samples were also detected by conventional RT-PCR, primers HC-157 F and HC72-518R, which were located at nt 157-179 and 518-497 of the $72-\mathrm{kDa}$ gene, and used to amplify the 360-bp band of interest. The primers CWMV-F and CWMV-R were used for
CWMV RT-PCR and primers BSMV-F and BSMV-R were used for BSMV RT-PCR (Table 1). Agarose gel analysis of RT-LAMP revealed that WYMV primers specifically amplified WYMV but not CWMV and BSMV, although CWMV and BSMV could infect wheat with WYMV in some regions of China [12] (Figure 5).

The sensitivity comparison showed that RT-LAMP could detect WYMV from total RNA diluted up to $10^{-5}$, and RT-PCR detected total RNA diluted up to $10^{-3}$; therefore, RT-LAMP was 100-fold more sensitive than conventional RT-PCR (Figure 6).

\section{Detection of wheat field samples}

Twenty-two samples from fields of different provinces were tested by RT-LAMP and RT-PCR. The cultivars including 11-6978,11-6982, 11-6984, 11-6987, 11-7081, 11-7082, 11-7083, 11-7000, 11-7084, 11-7085,11-7086, 11-7087 and 11-7090 and the positive wheat samples were collected in March 2011 from the virus-infected field of Jiangsu Province and kept at $-20^{\circ} \mathrm{C}$. The other samples were collected from wheat fields of Shandong Province, where there was no report of WYMV, in 2007. The detection results of RT-LAMP and RT-PCR were different. Eight of 22 samples were positive by RTLAMP, whereas only five samples were positive by RTPCR (half of agarose results were shown in Figure 7). This result confirmed the reliability and sensitivity of this RT-LAMP assay for routine detection.

\section{Discussion}

WYMV could be detected by the RT-LAMP method using the designed four sets of primers (I-IV) and M- 


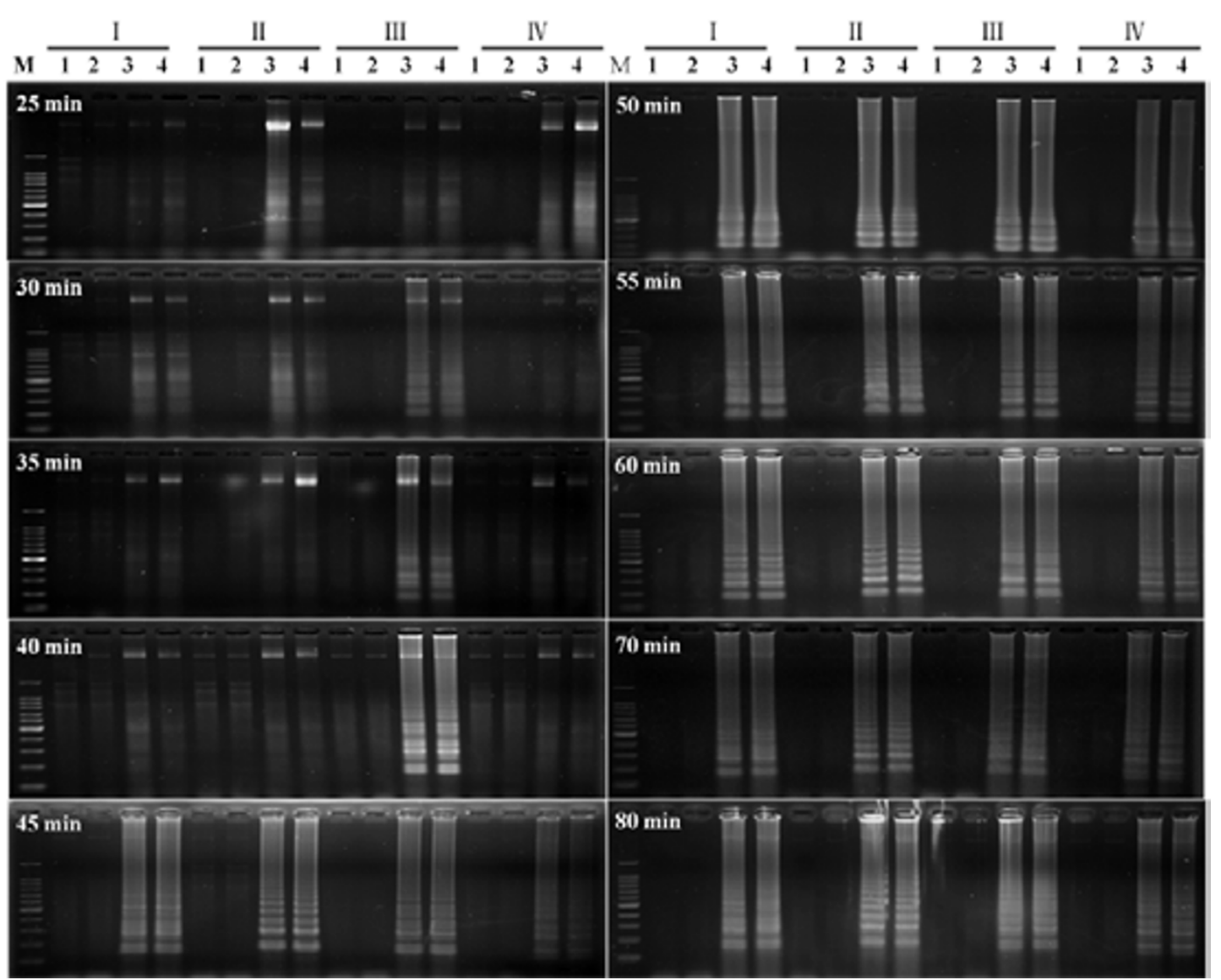

Figure 2 Agarose gel analysis of RT-LAMP with four primers sets at different reaction times. Total RNA was extracted from WYMVinfected wheat leaves and detected by RT-LAMP. I-IV were four sets of primers; M: 100-bp DNA ladder marker; 1 and 2: healthy controls; 3 and 4: positive controls

MLV reverse transcriptase instead of AMV reverse transcriptase under isothermal condition at $65^{\circ} \mathrm{C}$ for $80 \mathrm{~min}$.

The primer set III seemed more sensitive than the others and was selected for further virus detection in this study. The RT-LAMP assay was performed at different times and virus was detected after 30-45 min by agarose gel analysis, considering the field application where the turbidity will be observed by naked eyes as the criteria to judge that the sample is negative or positive, the reaction condition at $65^{\circ} \mathrm{C}$ for $80 \mathrm{~min}$ was used according to previous studies and the results obtained here. The RT-LAMP method had detection sensitivity about 100 times more than RT-PCR in the present study, which was similar to that reported by Boubourakas [33]. Therefore, RT-LAMP was demonstrated to be a simple and time-saving method compared with RTPCR for routine detection of WYMV, and it did not require specialized PCR and electrophoresis equipment. Due to the high level of detection sensitivity of the RTLAMP method, careful and strict operation was necessary during the whole process to avoid false-positive results [34]. Other factors to consider are DNA smear and turbidity. Similar to products generated by PCR, DNA smear was present in the healthy control, which may due to an excess amount of RNA used in the reaction and some non-specific reactions [31]. If the DNA smear is strong enough, it can influence observation of turbidity. Turbidity can be observed directly, but DNA smear can also produce turbidity when the concentration of RNA template is sufficiently high. Therefore, when turbidity is used to differentiate positive and negative samples, the amount of RNA template should be maintained at a low level.

\section{Conclusion}

In conclusion, this study developed the RT-LAMP assay for detecting WYMV. Compared with conventional RTPCR, RT-LAMP yielded more accurate results, and was more convenient and less time-consuming especially for field detection. This method has potential application in early diagnosis and screening of resistant wheat varieties, to reduce the loss of yield. 


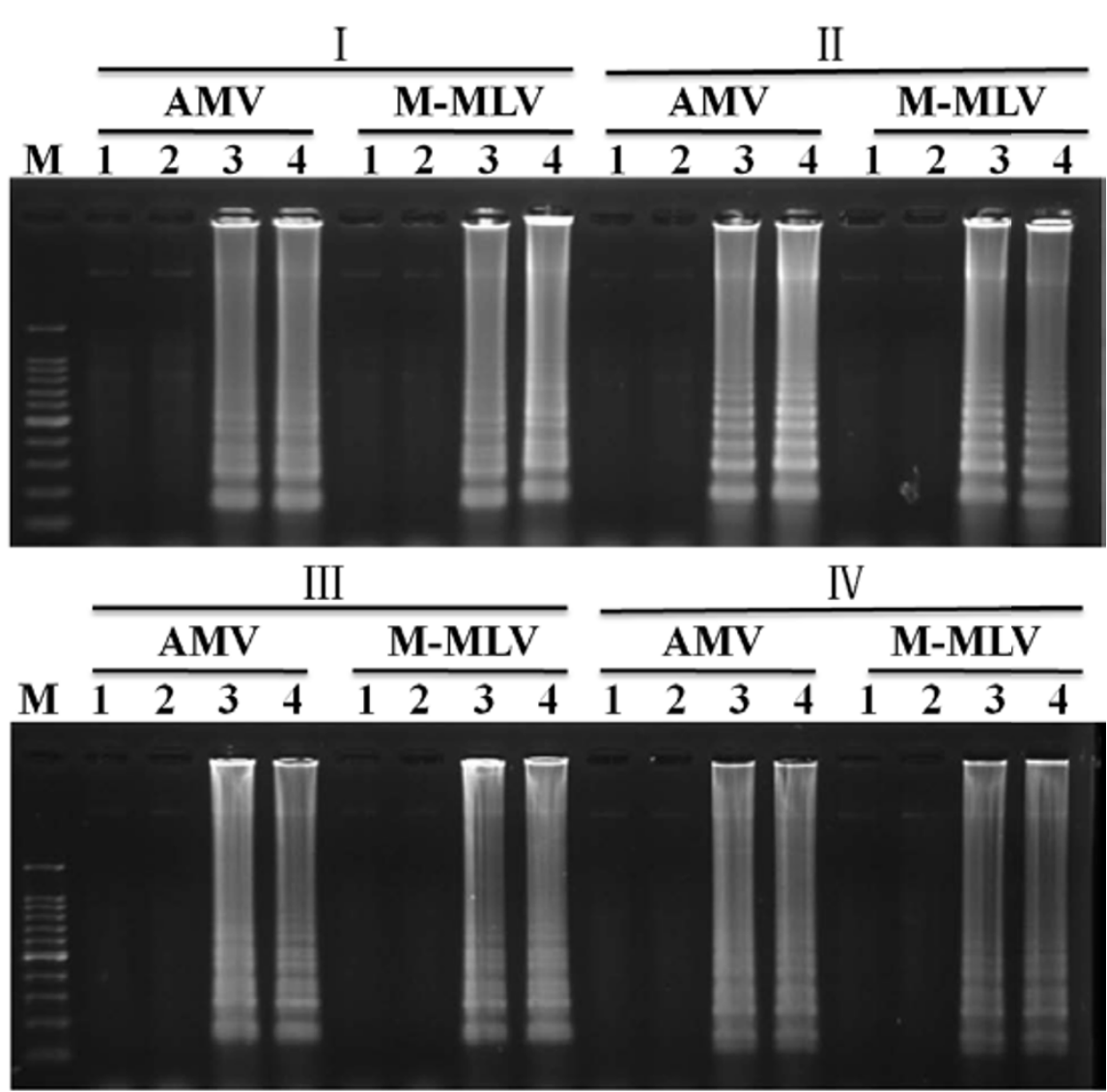

Figure 3 Agarose gel analysis of different RT-LAMP reactions. I-IV were four sets of primers; AMV was AMV-mediated RT-LAMP; M-MLV was M-MLV-mediated RT-LAMP. M: 100-bp DNA ladder marker; 1 and 2: healthy controls; 3 and 4: virus-infected samples

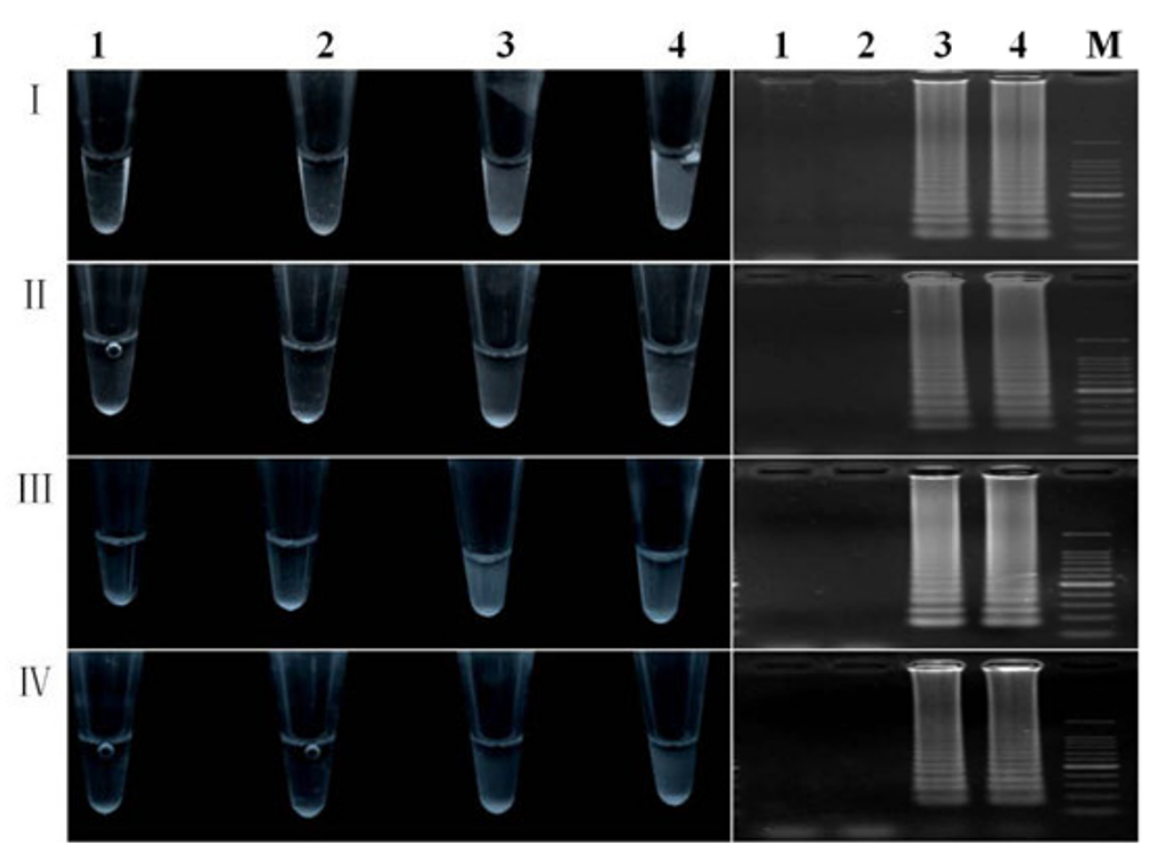

Figure 4 RT-LAMP reaction mixture turbidity (left) and agarose gel analysis (right). I-IV were four sets of primers. M: 100-bp DNA ladder marker; 1 and 2: healthy controls; 3 and 4: WYMV-infected samples 

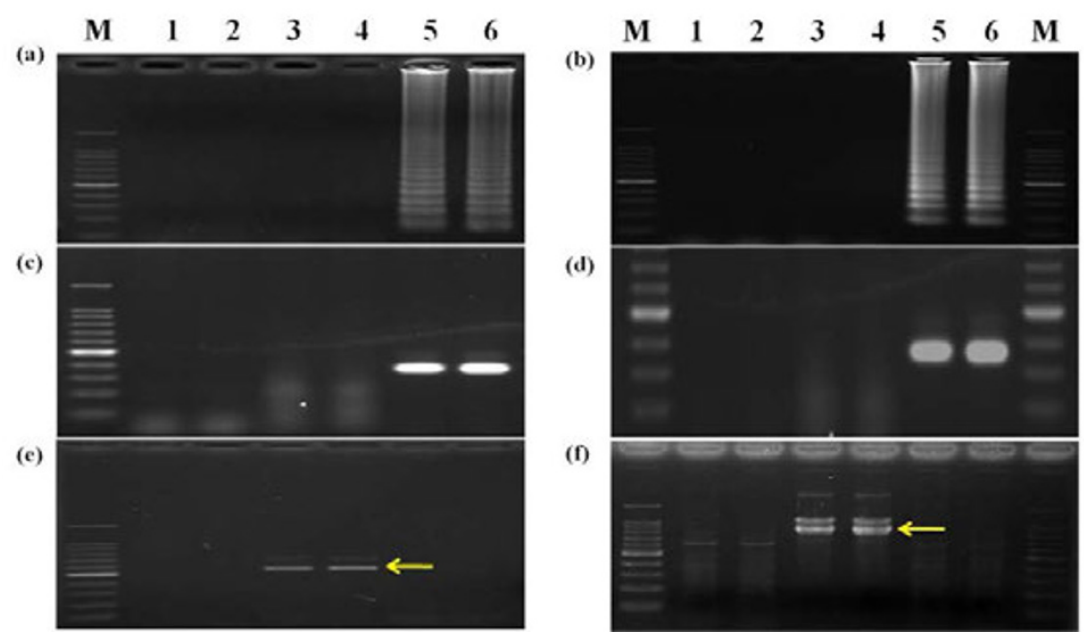

Figure 5 Specificity of primers for WYMV-infected samples by agarose gel analysis. (a) and (b) were RT-LAMP; (c) and (d) were RT-PCR for WYMV; (e) was RT-PCR for CWMV; (f) was RT-PCR for BSMV. The arrows showed the CWMV-positive band (left) and BSMV-positive band (right). M: 100-bp DNA ladder marker; 1 and 2: healthy controls; 3 and 4: CWMV-infected wheat leaves (left) and BSMV-infected wheat leaves (right); 5 and 6: WYMV-infected wheat leaves

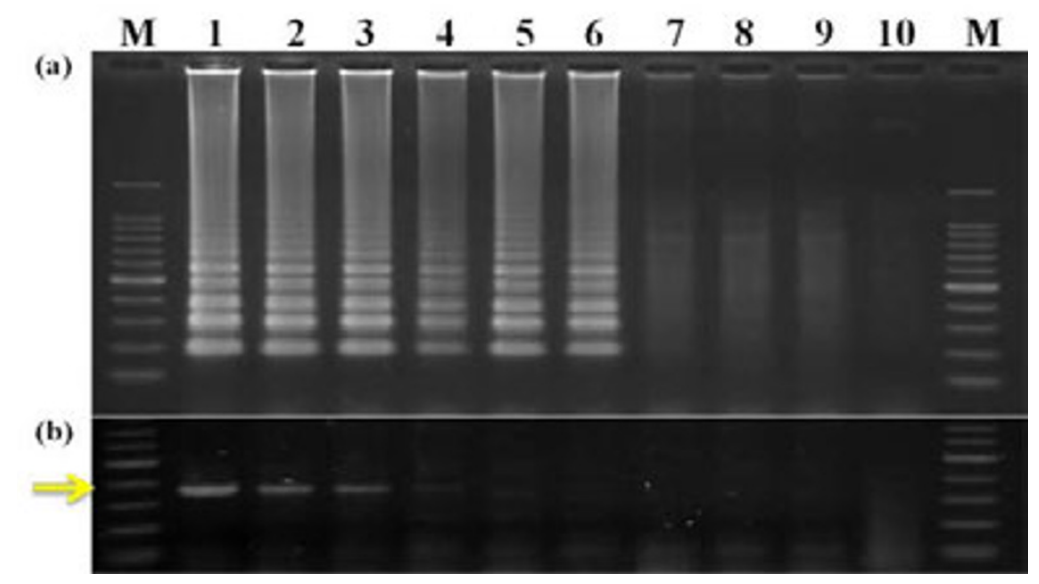

Figure 6 Comparison of detection sensitivity between RT-LAMP and RT-PCR for WYMV. Total RNA extract was serially diluted in 10-fold increments $\left(10^{0}\right.$ to $\left.10^{-8}\right)$ with healthy wheat RNAs. The arrow showed the positive band by RT-PCR. M: 100-bp DNA ladder marker; 1-9: total RNA dilution $\left(10^{0}\right.$ to $\left.10^{-8}\right) ; 10$ : healthy control

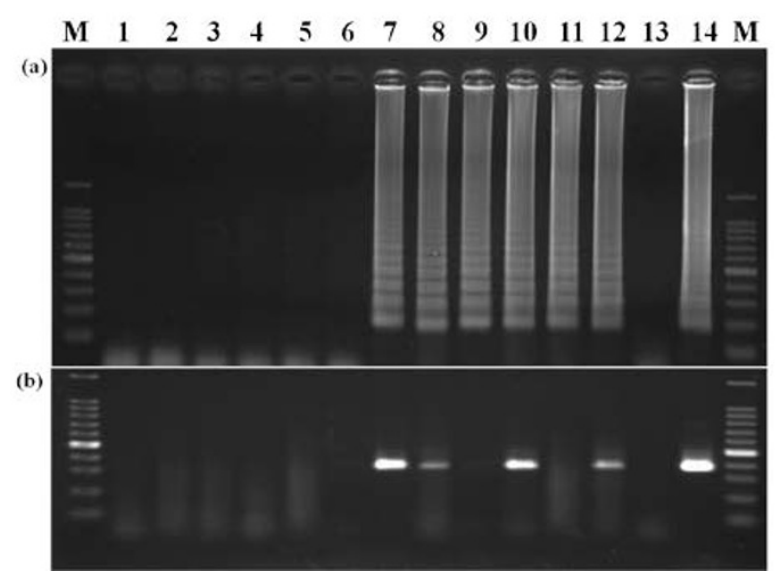

Figure 7 Detection of field samples by RT-LAMP (a) and RT-PCR (b). M: 100-bp DNA ladder marker; 1-12: wheat samples collected from Yushan and Xiaqiao, Jiangsu Province: 11-6982, 11-6984, 11-6987, 11-7081, 11-7082, 11-7083, 11-7000, 11-7084, 11-7085,11-7086, 11-7087 and 117090, respectively; 13: healthy control; 14: positive control 


\section{Acknowledgements}

This research was supported partially by National Department Public Benefit Research Funds (nyhyzX07-051 and 2008ZX08002-001) and the Program for Changjiang Scholars and Innovative Research Team in University (IRT1042).

\section{Authors' contributions}

$\mathrm{ZZ}$ carried out most of the experiments and wrote the manuscript. XL performed the RT-PCR detection of CWMV and the DL, JY and CH conceived of the study and participated in its design and coordination. All authors read and approved the final manuscript

\section{Competing interests}

The authors declare that they have no competing interests.

Received: 22 September 2011 Accepted: 20 December 2011

Published: 20 December 2011

\section{References}

1. Sawada E: Control of wheat yellow mosaic virus. J Plant Prot 1927, 14:444-449.

2. Kusume T, Tamada T, Hattori H, Tsuchiya T, Kubo K, Abe H, Namba S, Tsuchizaki T, Kishi K, Kashiwazaki S: Identification of a new wheat yellow mosaic virus strain with specific pathogenicity towards major wheat cultivars grown in Hokkaido. Ann Phytopathol Soc J.Jn 1997, 63(2):107-109.

3. Wang M, Liu G, Lu X: A primary confirmation on wheat spindle streak mosaic virus occurring in China. Agric Sci Technol Sichuan 1980, 1:34-35.

4. Han C, Li D, Xing Y, Zhu K, Tian Z, Cai Z, Yu J, Liu Y: Wheat yellow mosaic virus widely occurring in wheat (Triticum aestivum) in China. Plant Dis 2000, 84(6):627-630.

5. Inouye T: Filamentous particles as the causal agent of yellow mosaic disease of wheat. Nogaku kenkyu 1969, 53:61-68.

6. Namba S, Kashiwazaki S, Lu X, Tamura M, Tsuchizaki T: Complete nucleotide sequence of wheat yellow mosaic bymovirus genomic RNAs. Arch Virol 1998, 143(4):631-643.

7. Li D, Yan L, Su N, Han C, Hou Z, Yu J, Liu Y: The nucleotide sequence of a Chinese isolate of wheat yellow mosaic virus and its comparison with a Japanese isolate. Arch Virol 1999, 144(11):2201-2206.

8. Hariri D, Delaunay T, Gomes L, Filleur S, Plovie C, Lapierre H: Comparison and differentiation of wheat yellow mosaic virus (WYMV), wheat spindle streak mosaic virus (WSSMV) and barley yellow mosaic virus (BaYMV) isolates using WYMV monoclonal antibodies. Eur J Plant Pathol 1996, 102(3):283-292.

9. Hariri D, Lapierre H, Filleur S, Plovie C, Delaunay T: Production and characterization of monoclonal antibodies to barley yellow mosaic virus and their use in detection of four bymoviruses. J Phytopathol 1996, 144(6):331-336.

10. Geng B, Han C, Zhai Y, Wang H, Yu J, Liu Y: Detection of wheat yellow mosaic virus by heterogeneous animal double-antibody sandwich ELISA. Virologica Sinica 2003, 18(1):76-78

11. Clover G, Henry C: Detection and discrimination of wheat spindle streak mosaic virus and wheat yellow mosaic virus using multiplex RT-PCR. Eur J Plant Pathol 1999, 105(9):891-896.

12. Yue H, Wu Y, Li Y, Wei T, Hou W, Wu K: Simultaneous detection of three wheat virus BSMV, BYDV-PAV, WYMV and WBD phytoplasma by multiplex PCR. Sci Agri Sin 2008, 41(9):2663-2669.

13. Xing Y, Su N, Li D, Yu J, Liu Y: Over-expression of $72 \mathrm{kDa}$ protein of wheat yellow mosaic virus in $E$. coli and preparation of its antiserum. Chin Sci Bull 2000, 45(6):525-528.

14. Dong J, He Z, Han C, Chen X, Zhang L, Liu W, Han Y, Wang J, Zhai Y, Yu J: Generation of transgenic wheat resistant to wheat yellow mosaic virus and identification of gene silence induced by virus infection. Chin $\mathrm{SCl}$ Bull 2002, 47(17):1446-1450

15. Han C, Li D, Yu J, liu L, Shang Q, Liu Y: Preparation and application of specific antiserum against wheat yellow mosaic virus coat protein expressed in E. coli cells. J Agric Biotechnol 2002, 10(4):373-376.

16. Zhang Z, Xu J, Han C, Li D, Yu J: Detective and complete sequence analysis of wheat yellow mosaic virus from Zhumadian in Henan Province. Acta Agriculturae Boreali-Sinica 2010, 25(2):5-11.

17. Usugi T, Saito Y: Relationship between wheat yellow mosaic virus and wheat spindle streak mosaic virus. Ann Phytopathol Soc Jpn 1979, 45:397-400.
18. Notomi T, Okayama H, Masubuchi H, Yonekawa T, Watanabe K, Amino N, Hase T: Loop-mediated isothermal amplification of DNA. Nucleic Acids Res 2000, 28(12):e63.

19. Mori Y, Nagamine K, Tomita N, Notomi T: Detection of loop-mediated isothermal amplification reaction by turbidity derived from magnesium pyrophosphate formation. Biochem Biophys Res Commun 2001, 289(1):150-154.

20. Thai H, Le M, Vuong C, Parida M, Minekawa H, Notomi T, Hasebe F, Morita K: Development and evaluation of a novel loop-mediated isothermal amplification method for rapid detection of severe acute respiratory syndrome coronavirus. J Clin Microbiol 2004, 42(5):1956.

21. Arita M, Ling H, Yan D, Nishimura Y, Yoshida H, Wakita T, Shimizu H: Development of a reverse transcription-loop-mediated isothermal amplification (RT-LAMP) system for a highly sensitive detection of enterovirus in the stool samples of acute flaccid paralysis cases. BMC Infect Dis 2009, 9(1):208.

22. Jiang T, Liu J, Deng Y, Xu L, Li X, Han J, Cao R, Qin E: Development and evaluation of a reverse transcription-loop-mediated isothermal amplification assay for rapid detection of Enterovirus 71. J Clin Microbiol 2011, 49(3):870.

23. Nagdev K, Kashyap R, Parida M, Kapgate R, Purohit H, Taori G, Daginawala $\mathrm{H}$ : Loop-mediated isothermal amplification for rapid and reliable diagnosis of tuberculous menngitis. J Clin Microbiol 2011, 49(5):1861-1865

24. Li S, Fang M, Zhou B, Ni H, Shen Q, Zhang H, Han Y, Yin J, Chang W, Xu G: Simultaneous detection and differentiation of dengue virus serotypes 14, Japanese encephalitis virus, and West Nile virus by a combined reverse-transcription loop-mediated isothermal amplification assay. Virol J 2011, 8(1):360

25. Parida M, Shukla J, Sharma S, Santhosh S, Ravi V, Mani R, Thomas M, Khare S, Rai A, Ratho R: Development and evaluation of reverse transcription loop-mediated isothermal amplification assay for rapid and real-time detection of the swine-origin influenza A H1N1 virus. J Mol Diagnostics 2011, 13(1):100-107.

26. Fukuta S, lida T, Mizukami Y, Ishida A, Ueda J, Kanbe M, Ishimoto Y: Detection of Japanese yam mosaic virus by RT-LAMP. Arch Virol 2003, 148(9):1713-1720.

27. Fukuta S, Kato S, Yoshida K, Mizukami Y, Ishida A, Ueda J, Kanbe M, Ishimoto $Y$ : Detection of tomato yellow leaf curl virus by loop-mediated isothermal amplification reaction. J Virol Methods 2003, 112(1-2):35-40.

28. Fukuta S, Nimi Y, Oishi K, Yoshimura Y, Anai N, Hotta M, Fukaya M, Kato T, Oya T, Kambe M: Development of reverse transcription loop-mediated isothermal amplification (RT-LAMP) method for detection of two viruses and chrysanthemum stunt viroid. Ann Rep Kansai Plant Protect Soc 2005, 47:31-36.

29. Fukuta S, Ohishi K, Yoshida K, Mizukami Y, Ishida A, Kanbe M: Development of immunocapture reverse transcription loop-mediated isothermal amplification for the detection of tomato spotted wilt virus from chrysanthemum. J Virol Methods 2004, 121(1):49-55.

30. Le DT, Netsu O, Uehara-Ichiki T, Shimizu T, Choi IR, Omura T, Sasaya T: Molecular detection of nine rice viruses by a reverse-transcription loopmediated isothermal amplification assay. J Virol Methods 2010, 170(12):90-93.

31. Nie X: Reverse transcription loop-mediated isothermal amplification of DNA for detection of Potato virus Y. Plant Dis 2005, 89(6):605-610.

32. Varga $A$, James $D$ : Use of reverse transcription loop-mediated isothermal amplification for the detection of plum pox virus. J Virol Methods 2006, 138(1-2):184-190.

33. Boubourakas I, Fukuta S, Kyriakopoulou P: Sensitive and rapid detection of peach latent mosaic viroid by the reverse transcription loop-mediated isothermal amplification. J Virol Methods 2009, 160(1-2):63-68.

34. Tomita N, Mori Y, Kanda H, Notomi T: Loop-mediated isothermal amplification (LAMP) of gene sequences and simple visual detection of products. Nat Protoc 2008, 3(5):877-882.

doi:10.1186/1743-422X-8-550

Cite this article as: Zhang et al:: Rapid detection of wheat yellow mosaic virus by reverse transcription loop-mediated isothermal amplification. Virology Journal 2011 8:550. 